Thorax (1976), 31, 271.

\title{
Effect of perfusion of bile salts solutions into the oesophagus of hiatal hernia patients and controls
}

\author{
G.S.BACHIR and J. LEIGH COLLIS \\ Oesophageal Laboratory, Department of Surgery, Birmingham Medical School, Birmingham
}

\begin{abstract}
Bachir, G. S. and Leigh Collis, J. (1976). Thorax, 31, 271-277. Effect of perfusion of bile salts solutions into the oesophagus of hiatal hernia patients and controls. Tests of the response to perfusion of the oesophagus were made in 54 patients divided into three groups. Group I consisted of patients with symptomatic hiatal hernia, group II hiatal hernia patients with peptic stricture, and group III normal individuals. Each individual oesophagus was perfused at a rate of 45-65 drops per minute over 25 minutes with six solutions: normal saline, $\mathrm{N} / 10 \mathrm{HCl}$, taurine conjugates of bile salts in normal saline, taurine conjugates of bile salts in $\mathrm{N} / 10 \mathrm{HCl}$, glycine conjugates of bile salts in normal saline, and taurine and glycine conjugates in a ratio of 1 to 2 in normal saline.

It was found that acidified taurine solutions were more irritating than acid alone. With a $2 \mathrm{mM} / 1$ solution of taurine in acid, symptoms are produced even in controls. With a $1 \mathrm{mM} / 1$ solution of the same conjugates, the majority of normal people feel slight heartburn or nothing, and therefore perfusion into the oesophagus of such a solution could be used as a test for oesophagitis.
\end{abstract}

Interest in the role of bile salts in the pathogenesis of gastric and oesophageal lesions is increasing. Cases of severe oesophagitis and ulceration following partial and total gastrectomies have been reported (Helsingen, 1960; Cox, 1961; Kleckner et al., 1972). Achlorhydria does not protect the oesophagus against these changes (Palmer, 1960). Himal and MacLean (1973) reported five cases of severe oesophagitis and heartburn after gastrointestinal surgery. A complete cure followed a bile-diverting operation.

Animal experiments on Rhesus monkeys have shown that the combination of bile with gastric juice has a greater effect on the oesophagus than has either singly (Gillison et al., 1972). Oesophageal perfusion with different bile salts in acid solution in anaesthetized dogs demonstrated a definite synergism of action between the two and a more noxious effect from the taurine conjugates of bile salts (Henderson et al., 1973). A high degree of correlation has been noticed between heartburn in sliding hiatal hernia patients and the radiological evidence of duodenogastric reflux (Gillison et al., 1969). Increased amounts of bile salts were found in the stomach of hiatal hernia patients as compared with normals (Stol, Murphy, and Leigh Collis, 1973), the taurine conjugates being predominant (Crumplin et al., 1974).

It seems that a duodenogastric reflux with gastro-oesophageal reflux in some hiatal hernia patients permits acidified bile to enter the oesophagus. The acidity of the stomach precipitates the glycine conjugates of bile salts, but the taurine conjugates remain dissolved. Usually the oesophagus of a patient with symptomatic hiatal hernia is bathed with an acidified taurine conjugate solution. With abnormal acidity or altered local mechanics glycine conjugates in solution may be found in the oesophagus.

In this study the sensitivity of the oesophageal mucosa of hiatal hernia patients has been tested to acid and solutions of the bile salts conjugates separately and in mixtures in normal saline and acid. The results are reported and discussed.

\section{MATERIAL AND METHODS}

Six solutions were used (Table I). Solution 1, normal saline; solution 2, taurine conjugates of bile 
T A B L E I

SOLUTIONS PERFUSED

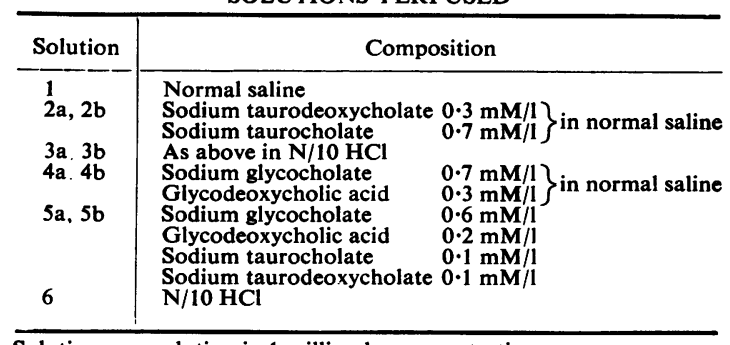

Solution a $=$ solution in 1 millimolar concentration

Solution $\mathrm{b}=$ solution in $\mathbf{2}$ millimolar concentration.

salts in normal saline; solution 3 , taurine conjugates of bile salts in $\mathrm{N} / 10 \mathrm{HCl}$; solution 4 , glycine conjugates of bile salts in normal saline; solution 5 , mixture of taurine and glycine conjugates of bile salts in normal saline $(G / T$ ratio $2: 1$, a ratio which is found in some people); solution $6 \mathrm{~N} / 10$ $\mathrm{HCl}$ only. The bile salts solutions were used in 1 and 2 millimolar concentrations per litre. The solutions of glycine conjugates in $\mathrm{N} / 10 \mathrm{HCl}$ were not used because glycine conjugates precipitate in acid solutions.

Fifty-four subjects were investigated, consisting of three groups (18 patients in each): group I, symptomatic hiatal hernia patients; group II, hiatal hernia patients with peptic stricture; group III, normal controls.

The symptoms of group I patients included nausea, vomiting, severe heartburn, pain, and variable degrees of discomfort from dysphagia and oesophagitis.

All patients in group II had dysphagia as their main symptom. All hiatal hernia patients underwent barium swallow, oesophagoscopy with biopsy, manometric studies, and overnight $\mathrm{pH}$ recordings. The controls and hiatal hernia patients were matched as far as possible for sex and age.

\section{METHOD}

A Salem double-lumen tube was introduced into the oesophagus so that its tip lay 5 to $10 \mathrm{~cm}$ above the gastro-oesophageal junction. The tube was joined by a T-tube to two bottles, one containing normal saline solution, the other one of the test solutions. The connecting tubes were made as short as possible to diminish the volume of fluid in the system. The bottles were not labelled. All the solutions had similar transparent appearances. The solution was run at speeds of 45-65 drops per minute for 25 minutes. Normal saline was used first, and then the other solutions followed random order.

As soon as a response was obtained, the pe fusion was stopped. The time to produce the response was recorded as the 'response time'. NoG mal saline was perfused at the same speed until the response had disappeared completely. This time is referred to as the 'washing time'. This procedure was repeated with the other solutions.

A record was made of the type of response ob tained, its degree, site, similarity of the symptom to those experienced by the patient, the time of its occurrence, the duration of the perfusion, the 'response time', and the 'washing time'.

\section{RESULTS}

Only two solutions provoked a response-solution $6, \mathrm{~N} / 10 \mathrm{HCl}$, and solution 3 , taurine conjugates o bile salts in $\mathrm{N} / 10 \mathrm{HCl}$.

In each group, patients 1-6 had perfusions of $1 \mathrm{mM} / 1$ solution. Solution 3 gave a shorter re sponse time and a longer washing time and geno erally produced a stronger response than solution $6, \mathrm{~N} / 10 \mathrm{HCl}$. However, these results were not uniform (exceptions being group I-patient 3, an $\$$ group II-patient 2) so that in patients $7-12$ a perfusion of 1 and $2 \mathrm{mM} / 1$ solutions was given $2 \mathrm{mM} / 1$ solution 3 gave a still shorter response time and a longer washing time and produced stronger response than $1 \mathrm{mM} / 1$ solution 3 and 6 $\mathrm{N} / 10 \mathrm{HCl}$.

The results were calculated in three comparable subgroups within each group. The first subgroup was patients 1-12 who had perfusions of $1 \mathrm{mM} / 9$ solution; the second subgroup, patients $7-18$, ha perfusions of $2 \mathrm{mM} / 1$ solution; and the third sub group, patients 7-12, had perfusions of 1 and 5 $\mathrm{mM} / 1$ solutions. When the patient showed no re? sponse during the perfusion, the response time was recorded as greater than 25 minutes and is taken as 25 minutes in counting the mean. The washings time of these patients was discarded. Tables $I_{\text {N }}$ III, and IV show the results of the response time and the washing time in groups I, II, and III Tables V, VI, and VII show the type, degree, and site of the response and the number of patient? responding.

\section{DISCUSSION}

The important role of bile in producing oeso phagitis is generally accepted. Perfusion of the human oesophagus with bile was performed aso early as 1926 (Jones and Richardson, 1926) and produced pain. However, similar perfusions were 
T A B L E I I

RESULTS OF OESOPHAGEAL PERFUSION OF N/10 $\mathrm{HCl}$ AND 1 AND $2 \mathrm{mM}$ SOLUTIONS OF TAURINE CONJUGATES OF BILE SALTS IN N/10 HCl: GROUP I (SYMPTOMATIC HIATAL HERNIA)

\begin{tabular}{|c|c|c|c|c|c|c|}
\hline \multirow[b]{2}{*}{ Patient } & \multicolumn{2}{|c|}{$\mathrm{N} / 10 \mathrm{HCl}$} & \multicolumn{2}{|c|}{$1 \mathrm{~T}+\mathrm{N} / 10 \mathrm{HCl}$} & \multicolumn{2}{|c|}{$2 \mathrm{~T}+\mathrm{N} / 10 \mathrm{HCl}$} \\
\hline & Response Time & Washing Time & Response Time & Washing Time & Response Time & Washing Time \\
\hline $\begin{array}{r}1 \\
2 \\
3 \\
4 \\
5 \\
6 \\
7 \\
8 \\
9 \\
10 \\
11 \\
12 \\
13 \\
14 \\
15 \\
16 \\
17 \\
18\end{array}$ & $\begin{array}{r}7 \\
12 \\
4 \\
4 \\
6 \\
>25 \\
>25 \\
18 \\
8 \\
25 \\
18 \\
>25 \\
20 \\
15 \\
7 \\
20 \\
9 \\
21\end{array}$ & $\begin{array}{l}0 \cdot 5 \\
6 \\
3 \\
2 \\
1 \\
- \\
5 \\
8 \\
7 \\
15 \\
4 \cdot 5 \\
9 \\
3 \cdot 5 \\
7 \\
6 \cdot 5\end{array}$ & $\begin{array}{r}4 \\
4 \\
21 \\
2 \\
2 \\
6 \\
4 \\
4 \\
5 \\
7 \\
12 \\
5\end{array}$ & $\begin{array}{r}10 \\
8 \\
12 \\
5 \\
6 \\
8 \\
5 \\
6 \\
13 \\
10 \\
18 \\
8\end{array}$ & $\begin{array}{r}4 \\
3 \\
2 \\
2 \\
4 \\
9 \\
9 \\
5 \\
6 \\
14 \\
4 \\
7 \\
9\end{array}$ & $\begin{array}{l}15 \\
17 \\
19 \\
18 \\
20 \\
22 \\
28 \\
35 \\
22 \cdot 5 \\
17 \\
20 \\
20\end{array}$ \\
\hline $\begin{array}{l}1-12 \\
7-18 \\
7-12\end{array}$ & $\begin{array}{l}14 \cdot 75 \\
17 \cdot 5 \\
19 \cdot 8\end{array}$ & $\begin{array}{l}4 \cdot 06 \\
7 \cdot 27 \\
6 \cdot 60\end{array}$ & $\begin{array}{l}6 \cdot 41 \\
6 \cdot 33\end{array}$ & $\begin{array}{r}9 \cdot 08 \\
10 \cdot 00\end{array}$ & $\begin{array}{l}5 \cdot 75 \\
4 \cdot 00\end{array}$ & $\begin{array}{l}21 \cdot 12 \\
18 \cdot 00\end{array}$ \\
\hline
\end{tabular}

$1 \mathrm{~T}+\mathrm{HCl}=1$ millimolar concentration of taurine conjugates of bile salts in $\mathrm{N} / 10 \mathrm{HCl}$ solution.

$2 \mathrm{~T}+\mathrm{HCl}=2$ millimolar concentration of taurine conjugates of bile salts in $\mathrm{N} / 10 \mathrm{HCl}$ solution.

Response time $=$ time needed for perfusion to produce a response (minutes).

Washing time $=$ time needed for the normal saline perfusion to wash the response away (minutes).

T A B L E I I I

RESULTS OF OESOPHAGEAL PERFUSION OF N/10 $\mathrm{HCl}$ AND 1 AND 2 mM SOLUTIONS OF TAURINE CONJUGATES OF BILE SALTS IN N/10 HCl: GROUP II (PEPTIC STRICTURE)

\begin{tabular}{|c|c|c|c|c|c|c|}
\hline \multirow[b]{2}{*}{ Patient } & \multicolumn{2}{|c|}{$\mathrm{N} / 10 \mathrm{HCl}$} & \multicolumn{2}{|c|}{$1 \mathrm{~T}+\mathrm{N} / 10 \mathrm{HCl}$} & \multicolumn{2}{|c|}{$2 \mathrm{~T}+\mathrm{N} / 10 \mathrm{HCl}$} \\
\hline & Response Time & Washing Time & Response Time & Washing Time & Response Time & Washing Time \\
\hline $\begin{array}{r}1 \\
2 \\
3 \\
4 \\
5 \\
6 \\
7 \\
8 \\
9 \\
10 \\
11 \\
12 \\
13 \\
14 \\
15 \\
16 \\
17 \\
18\end{array}$ & $\begin{array}{r}25 \\
9 \\
11 \\
9 \\
5 \\
8 \\
>25 \\
>25 \\
>25 \\
>25 \\
14 \\
17 \\
>25 \\
8 \\
20 \\
>25 \\
18 \\
14\end{array}$ & $\begin{array}{r}11 \\
7 \\
8 \\
9 \\
6 \\
2 \\
- \\
- \\
15 \\
15 \\
8 \\
8 \\
7 \\
6\end{array}$ & $\begin{array}{r}11 \\
15 \\
8 \\
9 \\
5 \\
7 \\
>25 \\
>25 \\
17 \\
8 \\
7 \\
15\end{array}$ & $\begin{array}{c}\text { Vomited tube } \\
20 \\
10 \\
8 \\
12 \\
14 \\
- \\
-4 \\
11 \\
12 \\
18\end{array}$ & $\begin{array}{r}7 \\
13 \\
11 \\
6 \\
7 \\
12 \\
11 \\
11 \\
6 \\
7 \\
6 \\
7\end{array}$ & $\begin{array}{l}32 \\
28 \\
26 \\
24 \\
37 \\
25 \\
24 \\
22 \\
22 \\
17 \\
18 \\
20\end{array}$ \\
\hline $\begin{array}{l}1-12 \\
7-18 \\
7-12\end{array}$ & $\begin{array}{l}16 \cdot 50 \\
19 \cdot 20 \\
21 \cdot 8\end{array}$ & $\begin{array}{c}9 \cdot 12 \\
8 \cdot 71 \\
15 \cdot 0\end{array}$ & $\frac{12 \cdot 66}{16 \cdot 66}$ & $\frac{12 \cdot 11}{11 \cdot 25}$ & $\begin{array}{l}8 \cdot 66 \\
9 \cdot 33\end{array}$ & $\begin{array}{l}24 \cdot 58 \\
28 \cdot 66\end{array}$ \\
\hline
\end{tabular}

See footnote to Table II.

not repeated. Perfusion of $\mathrm{N} / 10 \mathrm{HCl}$ into the oesophagus was suggested as a clinical test for oesophagitis in 1958 (Bernstein and Baker, 1958) and was used to distinguish between cardiac and oesophageal pain (Bennett and Atkinson, 1966).
Although oesophageal perfusion in animals showed the harmful effect of bile salt conjugates, different animals have different responses to bile (Arnold, 1974). Furthermore these perfusions were unphysiological concentrations to which 
T A B L E I V

RESULTS OF OESOPHAGEAL PERFUSION OF N/10 HCl AND 1 AND $2 \mathrm{mM}$ SOLUTIONS OF TAURINE CONJUGATES OF BILE SALTS IN N/10 HCl: GROUP III (CONTROLS)

\begin{tabular}{|c|c|c|c|c|c|c|}
\hline \multirow[b]{2}{*}{ Patient } & \multicolumn{2}{|c|}{$\mathrm{N} / 10 \mathrm{HCl}$} & \multicolumn{2}{|c|}{$1 \mathrm{~T}+\mathrm{N} / 10 \mathrm{HCl}$} & \multicolumn{2}{|c|}{$2 \mathrm{~T}+\mathrm{N} / 10 \mathrm{HCl}$} \\
\hline & Response Time & Washing Time & Response Time & Washing Time & Response Time & Washing Time \\
\hline $\begin{array}{r}1 \\
2 \\
3 \\
4 \\
5 \\
6 \\
7 \\
8 \\
9 \\
10 \\
11 \\
12 \\
13 \\
14 \\
15 \\
16 \\
17 \\
18\end{array}$ & $\begin{array}{r}>25 \\
>25 \\
>25 \\
>25 \\
8 \\
>25 \\
>25 \\
19 \\
6 \\
17 \\
99 \\
>25 \\
>25 \\
20 \\
>25 \\
>25 \\
>25 \\
>25\end{array}$ & $\begin{array}{l}\bar{E} \\
\bar{E} \\
\overline{4} \\
\overline{15} \\
3 \\
3 \\
5 \\
\overline{5} \\
= \\
= \\
-\end{array}$ & $\begin{array}{r}>25 \\
>25 \\
13 \\
12 \\
6 \\
>25 \\
>25 \\
14 \\
5 \\
12 \\
7 \\
>25\end{array}$ & $\begin{array}{l}\overline{-} \\
12 \\
14 \\
9 \\
\overline{18} \\
14 \\
19 \\
10 \\
-\end{array}$ & $\begin{array}{r}13 \\
5 \\
5 \\
7 \\
5 \\
14 \\
10 \\
15 \\
12 \\
14 \\
6 \\
5\end{array}$ & $\begin{array}{l}26 \\
30 \\
20 \\
22 \\
23 \\
28 \\
22 \\
18 \\
24 \\
26 \\
28 \\
27\end{array}$ \\
\hline $\begin{array}{l}1-12 \\
7-18 \\
7-12\end{array}$ & $\begin{array}{l}19 \cdot 50 \\
19 \cdot 5 \\
16 \cdot 8\end{array}$ & $\begin{array}{l}6 \cdot 2 \\
7 \cdot 0 \\
6 \cdot 5\end{array}$ & $\begin{array}{l}16 \cdot 16 \\
14 \cdot 66\end{array}$ & $\begin{array}{l}13 \cdot 71 \\
15 \cdot 25\end{array}$ & $\begin{array}{l}9 \cdot 25 \\
8 \cdot 16\end{array}$ & $\begin{array}{l}24 \cdot 5 \\
24 \cdot 83\end{array}$ \\
\hline
\end{tabular}

See footnote to Table II.

T A B L E V

TYPES OF RESPONSE OCCURRING DURING PERFUSION IN GROUP I (SYMPTOMATIC HIATAL HERNIA)

\begin{tabular}{|c|c|c|c|c|c|c|c|}
\hline \multirow[b]{2}{*}{ Symptom } & \multirow[b]{2}{*}{ Solution perfused } & \multirow[b]{2}{*}{ Occurrence $^{1} \%$} & \multirow[b]{2}{*}{$\underset{\text { Coefficient }^{2}}{\text { Similarity }}$} & \multicolumn{2}{|c|}{ Degree } & \multicolumn{2}{|c|}{ Site } \\
\hline & & & & $\underset{\text { Moderate }}{\text { Mild }}$ & Severe & Sternal & Epigastric \\
\hline $\begin{array}{l}\text { Heartburn } \\
\text { Pain }\end{array}$ & $\begin{array}{c}\mathrm{HCl} \\
1 \mathrm{~T}+\mathrm{HCl} \\
2 \mathrm{~T}+\mathrm{HCl} \\
\mathrm{HCl} \\
1 \mathrm{~T}+\mathrm{HCl} \\
2 \mathrm{~T}+\mathrm{HCl}\end{array}$ & $\begin{array}{r}77 \cdot 7(14 / 18) \\
91 \cdot 0(11 / 12) \\
100 \quad(12 / 12) \\
22 \cdot 2 \quad(4 / 18) \\
33 \cdot 3(4 / 12) \\
75 \cdot 0 \quad(9 / 12)\end{array}$ & $\begin{array}{r}14 / 17 \\
11 / 11 \\
12 / 12 \\
4 / 15 \\
4 / 10 \\
9 / 10\end{array}$ & $\begin{array}{c}14 / 14 \\
7 / 11 \\
4 / 4 \\
4 / 4\end{array}$ & $\begin{array}{r}4 / 11 \\
12 / 12 \\
9 / 9\end{array}$ & $\begin{array}{c}14 / 14 \\
9 / 11 \\
12 / 12 \\
4 / 4 \\
4 / 4 \\
7 / 9\end{array}$ & $\begin{array}{l}3 / 14 \\
3 / 11 \\
6 / 12 \\
3 / 4 \\
2 / 4 \\
6 / 9\end{array}$ \\
\hline Nausea & $\begin{array}{c}\mathrm{HCl} \\
1 \mathrm{~T}+\mathrm{HCl}+\mathrm{HCl}\end{array}$ & $\begin{array}{cc}16 \cdot 6 & (3 / 18) \\
100 & (8 / 12) \\
& (12 / 12)\end{array}$ & $\begin{array}{c}3 / 11 \\
8 / 8 \\
12 / 8\end{array}$ & $\begin{array}{l}3 / 3 \\
6 / 8\end{array}$ & $\begin{array}{l}2 / 8 \\
12 / 12\end{array}$ & & \\
\hline Vomiting & $\begin{array}{c}\mathrm{HCl} \\
1 \mathrm{~T}+\mathrm{HCl} \\
2 \mathrm{~T}+\mathrm{HCl}\end{array}$ & $\begin{array}{c}25 \cdot 0^{0}(3 / 12) \\
100(12 / 12)\end{array}$ & $\begin{array}{c}0 / 11 \\
3 / 8 \\
12 / 8\end{array}$ & $2 / 3$ & $\begin{array}{c}1 / 3 \\
12 / 12\end{array}$ & & \\
\hline
\end{tabular}

1Percentage of patients who had symptoms during the perfusion to the number of patients who had the perfusion.

${ }^{2}$ Number of patients who had symptoms reproduced during the perfusion divided by the number of patients who had symptoms in their history.

T A B L E V I

TYPES OF RESPONSE OCCURRING DURING PERFUSION IN GROUP II (PEPTIC STRICTURE)

\begin{tabular}{|c|c|c|c|c|c|c|c|}
\hline \multirow[b]{2}{*}{ Symptom } & \multirow[b]{2}{*}{ Solution perfused } & \multirow[b]{2}{*}{ Occurrence \% } & \multirow[b]{2}{*}{$\begin{array}{l}\text { Similarity } \\
\text { Coefficient }\end{array}$} & \multicolumn{2}{|c|}{ Degree } & \multicolumn{2}{|c|}{ Site } \\
\hline & & & & $\begin{array}{c}\text { Mild } \\
\text { Moderate }\end{array}$ & Severe & Sternal & Epigastric \\
\hline & $\begin{array}{c}\mathrm{HCl} \\
1 \mathrm{~T}+\mathrm{HCl} \\
2 \mathrm{~T}+\mathrm{HCl}\end{array}$ & $\begin{array}{l}44.4(8 / 18) \\
66 \cdot 6(8 / 12) \\
66 \cdot 6(8 / 12)\end{array}$ & $\begin{array}{l}8 / 12 \\
8 / 10 \\
8 / 7\end{array}$ & $\begin{array}{l}8 / 8 \\
2 / 8\end{array}$ & $\begin{array}{l}6 / 8 \\
8 / 8\end{array}$ & $\begin{array}{l}8 / 8 \\
4 / 8 \\
4 / 8\end{array}$ & $\begin{array}{l}8 / 8 \\
6 / 8 \\
8 / 8\end{array}$ \\
\hline Pain & $\mathrm{HCl}$ & $\begin{array}{l}33 \cdot 3(6 / 18) \\
50.0(6 / 12)\end{array}$ & $\begin{array}{l}6 / 17 \\
6 / 11\end{array}$ & $\begin{array}{l}6 / 6 \\
2 / 6\end{array}$ & $4 / 6$ & $\begin{array}{l}6 / 6 \\
6 / 6\end{array}$ & $6 / 6$ \\
\hline Nausea & $\begin{array}{l}2 \mathrm{~T}+\mathrm{HCl} \\
+\mathrm{HCl}\end{array}$ & $\begin{array}{l}66.6(8 / 12) \\
22 \cdot 2(4 / 18)\end{array}$ & $\begin{array}{l}8 / 8 \\
4 / 14\end{array}$ & $4 / 4$ & & & \\
\hline & $\begin{array}{l}1 \mathrm{~T}+\mathrm{HCl} \\
2 \mathrm{~T}+\mathrm{HCl}\end{array}$ & $\begin{array}{l}33.3(4 / 12) \\
66 \cdot 6(8 / 12)\end{array}$ & $\begin{array}{l}4 / 9 \\
8 / 8\end{array}$ & $3 / 4$ & $\begin{array}{l}1 / 4 \\
8 / 8\end{array}$ & & \\
\hline Vomiting & $\begin{array}{r}\mathrm{HCl} \\
1 \mathrm{~T}+\mathrm{HCl}\end{array}$ & $\begin{array}{r}5.0(1 / 18) \\
16.6(2 / 12)\end{array}$ & $\begin{array}{l}1 / 14 \\
2 / 9\end{array}$ & $\begin{array}{l}1 / 1 \\
1 / 2\end{array}$ & $1 / 2$ & & \\
\hline
\end{tabular}


T A B L E V I I

TYPES OF RESPONSE OCCURRING DURING PERFUSION IN GROUP III (CONTROLS)

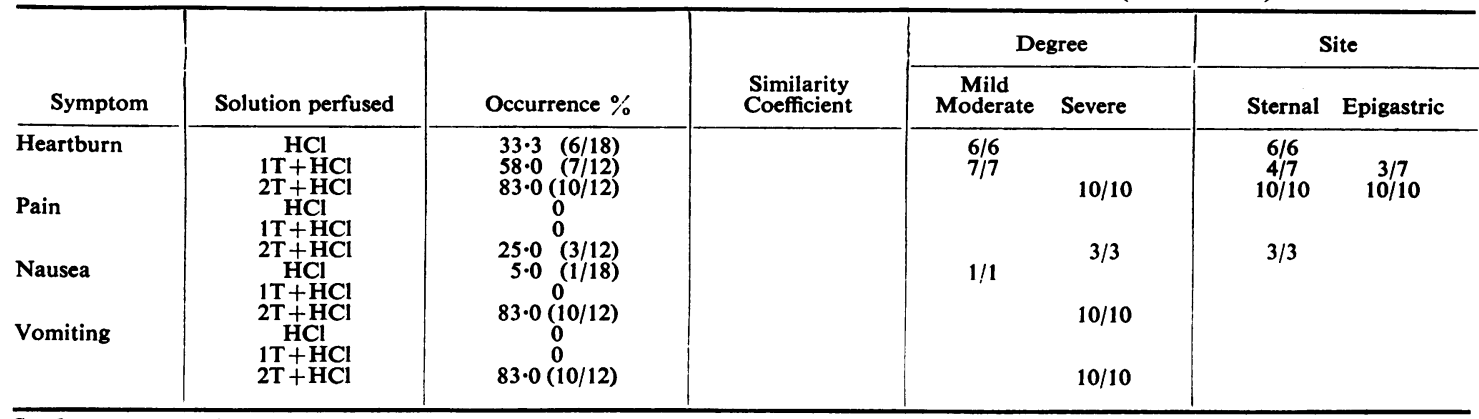

See footnote to Table V.

neither the human nor the animal oesophagus would normally be subjected. The role of bile salts in the pathogenesis of hiatal hernia symptoms is still not clearly defined.

Bile salts in the gastric juice of hiatal hernia patients rise to a $2 \mathrm{mM} / 1$ concentration (Bachir, 1974). A perfusion of $1 \mathrm{mM} / 1$ solution of bile salts into the oesophagus of hiatal hernia patients was undertaken, tentatively to assess the reactivity of the oesophageal mucosa. Similar perfusions were performed with a $5 \mathrm{mM} / 1$ solution of taurine conjugates of bile salts in two patients with pernicious anaemia who had developed oesophagitis (Orlando and Bozymski, 1973). All the symptoms of oesophagitis were reproduced by this test. Our studies assessed the reaction of the oesophagus in hiatal hernia patients to different bile salt conjugates and compared these with their reaction to $\mathrm{N} / 10 \mathrm{HCl}$ and to the combination of both.

The speed and the duration of the perfusion were chosen empirically. The results of perfusion in the first six patients revealed a difference in the speed of onset and the quality of the response between the $\mathrm{N} / 10 \mathrm{HCl}$ and $1 \mathrm{mM} / 1$ solution of taurine conjugates in $\mathrm{N} / 10 \mathrm{HCl}$. This difference was found constantly by independent observers. It was assumed that if the taurine conjugates were responsible for the exaggeration in the response, the increase in their concentration would exaggerate the response still further. Hence in the next six patients perfusion was given in 1 and $2 \mathrm{mM} / 1$ concentrations of all solutions. As expected, the response was noticeably stronger in type and quality as it regularly included the occurrence of severe heartburn, pain, nausea, and vomiting. The pattern persisted in the last six patients who had a perfusion of $2 \mathrm{mM} / 1$ solutions only. By the time the normal saline reached the oesophagus it had already displaced the taurine solution hence there was always an early period in the washing time when the response increased before it improved and finally disappeared. It was remarkable that the perfusion of taurine conjugates in acid always provoked the symptoms of hiatal hernia in a progressive way, heartburn occurring first, followed by pain, nausea, and vomiting. The patients were able to recognize the similarity of the induced symptoms to their usual symptoms, and to distinguish which of the solutions produced this effect most accurately. Group I patients stated that the $1 \mathrm{mM} / 1$ solution produced symptoms very similar to those they usually suffered whereas the symptoms that occurred with the $2 \mathrm{mM} / 1$ solution were more severe. Group II patients recognized a similarity of the heartburn produced by $1 \mathrm{mM} / 1$ solution to the heartburn they had had over the years. They had never experienced the symptoms that the $2 \mathrm{mM} / 1$ solution produced. Group III patients admitted that they did occasionally have heartburn similar to that produced by the $1 \mathrm{mM} / 1$ solution. However, they never suffered from symptoms similar to those occurring during the perfusion of the $2 \mathrm{mM} / 1$ solution.

The volume of solution necessary to produce a response varied markedly between one patient and another.

From the results of the response times it is clear that the combination of taurine conjugates and $\mathrm{N} / 10 \mathrm{HCl}$ has a stronger effect on the human oesophagus than the effect of either alone. The response time has been shorter with the $1 \mathrm{mM} / 1$ solution and still shorter with the $2 \mathrm{mM} / 1$ solution. The noxious influence of this combination could be seen from the increase in the washing time using the $1 \mathrm{mM} / 1$ solution as compared with the washing time using $\mathrm{N} / 10 \mathrm{HCl}$ in patients $1-12$, 
and in the greater increase in the washing time using the $2 \mathrm{mM} / 1$ solution in patients $7-18$, and certainly to the response to $\mathrm{N} / 10 \mathrm{HCl}$ in patients 1-18 in all three groups (Tables II-IV). This could be more clearly demonstrated by looking at the types of response these solutions produced. Table $\mathrm{V}$ shows this in group I. N/10 $\mathrm{HCl}$ produced heartburn in $77.7 \%$, a $1 \mathrm{mM} / 1$ solution in $91 \%$, and a $2 \mathrm{mM} / 1$ solution in $100 \%$ of patients who had the perfusion. However, N/10 $\mathrm{HCl}$ did not produce heartburn in three patients who suffered from it while the other two solutions produced heartburn in those with heartburn before test. Pain was produced by $\mathrm{N} / 10 \mathrm{HCl}$ in $22.2 \%$ of patients, by a $1 \mathrm{mM} / 1$ solution in $33.3 \%$, and by a $2 \mathrm{mM} / 1$ solution in $75 \%$. Conversely $\mathrm{N} / 10 \mathrm{HCl}$ produced pain in 4 out of 15 heartburn sufferers, the $1 \mathrm{mM} / 1$ solution in 4 out of 10 , and the $2 \mathrm{mM} / 1$ solution in 9 out of 10 . Nausea occurred in $16.6 \%$ of patients who had $\mathrm{N} / 10 \mathrm{HCl}$, that is, in three patients out of 11 who suffer from it; in none of them was the nausea severe enough to proceed to vomiting. A $2 \mathrm{mM} / 1$ solution caused nausea and vomiting in all 12 patients $(100 \%)$ who had the perfusion, four of whom did not have these symptoms during their illness. It is evident from the above that the taurine conjugates in acid solution were able to reproduce the symptoms of hiatal hernia patients better than $\mathrm{N} / 10 \mathrm{HCl}$.

The results of group II in Table VI and of group III in Table VII show a similar pattern of response to the three solutions. Nevertheless the progress in the build-up of symptoms did not take place in two patients (9-12, Table III) in group II (Table VI) who experienced only nausea during the perfusion of $1 \mathrm{mM} / 1$ solution and in four patients $(12,13,14$, and 17) in the same group who developed pain, nausea, and vomiting without heartburn in response to a $2 \mathrm{mM} / 1$ solution. The same applied to two patients (14 and 16, Table IV) in group III (Table VII) who had only pain without either heartburn or nausea or vomiting. However, the perfusion of these solutions gave a response in a smaller proportion of patients in group II than in group I, and this seems to be true for any symptoms occurring with all solutions. In the control group (Table VII) $\mathrm{N} / 10 \mathrm{HCl}$ caused mild heartburn in $33.3 \%$ while a $1 \mathrm{mM} / 1$ solution caused heartburn in $58 \%$, being mild in all. N/10 $\mathrm{HCl}$ produced nausea in a single patient, a $2 \mathrm{mM} / 1$ solution caused heartburn in 10 out of $12(83 \%)$, all of whom developed nausea and vomiting. One patient felt severe retrosternal pain immediately before the nausea and vomiting. The results of the perfusion of $\mathrm{N} / 10 \mathrm{HCl}$ and $1 \mathrm{mM} / 1$ solutions are in contrast to the results of perfusion in group $\frac{\vec{P}}{8}$ and to a lesser extent in group II. All these groups responded to a $2 \mathrm{mM} / 1$ solution. Nevertheles; there were fewer patients who reacted in group ( 8 out of 12) and in group III (10 out of 12) as compared to group I, where all the 12 patients rê sponded. The fact that the same molar solutio $\vec{\oplus}$ in normal saline did not provoke any response suggests that the causes of oesophagitis and ulcery. tion in postgastrectomy patients and in pernicious anaemia patients with achlorhydria include factors other than bile salts alone, pancreatic and biliary enzymes for example. These enzymes may pass into the oesophagus during a meal (Bachir, 1974) More important is the finding that the concentras tion of a $1 \mathrm{mM} / 1$ solution which reproduces hiata hernia symptoms could be present in the oesephagus of these patients (Bachir, 1974), a factor which cannot be ignored when considering the pathogenesis of hiatal hernia symptoms. The site of the pain in all patients was either retrostern or epigastric which may allow the perfusion to be used as a clinical test to distinguish between the pain of oesophagitis and pain originating else where. The taurine conjugates used in this te have a purity of $96-98 \%$. The impurity is formed by deoxycholic and cholic acids. Three to sith grams of both are given during one test. Th amount is unlikely to cause any hazard (Wiltzleben, 1972; Rauen et al., 1973).

\section{CONCLUSION}

1. Oesophageal perfusion of 1 and 2 millis molar/l solutions of glycine and taurine conjugates. in normal saline have no effect on the humagi oesophagus.

2. Both $\mathrm{N} / 10 \mathrm{HCl}$ solutions and taurine com jugates solutions in $\mathrm{N} / 10 \mathrm{HCl}$ provoked a response in hiatal hernia patients and controls.

3. Taurine conjugates solutions had a shorte⿸广 response time and a longer washing time thage $\mathrm{N} / 10 \mathrm{HCl}$.

4. A $1 \mathrm{mM} / 1$ solution of taurine conjugates $\mathrm{N} / 10 \mathrm{HCl}$ is able to reproduce the symptoms of hiatal hernia more accurately and in a greater proportion of patients than is $\mathrm{N} / 10 \mathrm{HCl}$ alone. $\frac{C}{\mathrm{D}}$

5. A $2 \mathrm{mM} / 1$ solution of taurine conjugates $\mathrm{N} / 10 \mathrm{HCl}$ provoked stronger responses that $1 \mathrm{mM} / 1$ of taurine conjugates in $\mathrm{N} / 10 \mathrm{HCl}$ and $\mathrm{N} / 10 \mathrm{HCl}$ alone in hiatal hernia patients anfif controls.

6. Hiatal hernia patients are more sensitive fo a $1 \mathrm{mM} / 1$ solution of taurine conjugates in $N / \% 0$ $\mathrm{HCl}$ than controls. The symptomatic hiatal hernga 
patients were more sensitive than the stricture group.

7. The perfusion of a $1 \mathrm{mM} / 1$ solution of taurine conjugates in $\mathrm{N} / 10 \mathrm{HCl}$ may be used as a clinical test to investigate hiatal hernia symptoms.

We are most grateful to Janet Williams and David Butler for their help in preparing the solutions and to Dr. Flynn for his help with the statistical analysis.

\section{REFERENCES}

Arnold, K. (1974). Personal communication.

Bachir, G. S. (1974). Unpublished data.

Bennett, J. R. and Atkinson, N. (1966). Oesophageal acid-perfusion in the diagnosis of pre-cordial pain. Lancet, 2, 1150.

Bernstein, L. M. and Baker, L. A. (1958). A clinical test for esophagitis. Gastroenterology, 34, 760.

Cox, K. R. (1961). Oesophageal stricture after partial gastrectomy. British Journal of Surgery, 49, 307.

Crumplin, M. K. H., Stol, D. W., Murphy, G. M., and Collis, J. L. (1974). The pattern of bile salt reflux and acid secretion in sliding hiatal hernia. British Journal of Surgery, 61, 611.

Gillison, E. W., Capper, W. M., and Airth, G. R. (1969). Hiatus hernia and heartburn. Gut, 10, 609.

_-, DeCastro, V. A. M., and Nyhus, L. M. (1972). The significance of bile in reflux oesophagitis. Surgery, Gynaecology and Obstetrics, 134, 419.

Helsingen, N., Jr. (1960). Oesophagitis following total gastrectomy. Acta Chirurgica Scandinavica, 118, 190.

Henderson, R. D., Mugashe, F. L., Jeejeebhoy, K. N., Szczpanski, M. M., Cullen, J., Marryatt, G., and
Boszko, A. (1973). Synergism of acid and bile salts in the production of experimental oesophagitis. Canadian Journal of Surgery, 16, 12.

Himal, H. S. and MacLean, L. D. (1973). Bile esophagitis. Canadian Journal of Surgery, 16, 17.

Jones, C. M. and Richardson, W. (1926). Observations on the nature of 'heart-burn'. Journal of Clinical Investigation, 2, 610.

Kleckner, F. S., Stahler, E. J., Hartzell, C., Jr., and Eicher, W. P. (1972). Esophagitis and gastritis secondary to bile reflux. Gastroenterology, 62, 890.

Orlando, R. C. and Bozymski, E. M. (1973). Heartburn in pernicious anaemia - a consequence of bile reflux 1973. New England Journal of Medicine, 289, 522.

Palmer, E. D. (1960). Subacute erosive (peptic) esophagitis associated with achlorhydria. New England Journal of Medicine, 262, 927.

Rauen, H. M., Schriewer, H., and Gebauer, et al. (1973). Die hepatotoxische Wirkung von Desoxycholat: ein Modell der multivariaten Analyse experimenteller Leberschädigungen. Arzneimittel -Forschung, 23, Supplement 127.

Stol, D. W., Murphy, G. M., and Leigh Collis, J. (1973). Duodeno-gastric reflux and acid secretion in patients with symptomatic hiatal hernia. Scandinavian Journal of Gastro-Enterology, 9, 97.

Wiltzleben, C. L. (1972). Hepatic ultrastructural effects of cholic acid overload. Experimental and Molecular Pathology, 16, 47.

Requests for reprints to: Professor J. Leigh Collis, The Queen Elizabeth Hospital, Edgbaston, Birmingham B15 2TH. 